\title{
Involusi Pertanian Di Jawa 1830-1900 dan Dampaknya Terhadap Kehidupan Masyarakat Desa
}

\author{
Syahbuddin \\ STKIP Taman Siswa Bima \\ oribedo70@gmail.com
}

\begin{abstract}
ABSTRAK
Penelitian ini bertujuan untuk menalaah kebijakan pemerintah kolonial Belanda sejak 1830-1900, dimana dalam rentang waktu di atas terapkan dua sistem yaitu tanam paksa dan liberal. Penelitian ini merupakan penelitian sejarah yang terdiri dari heuristik, kritik, Interprerasi dan historiografi. Peneliti menggunakan pendekatan ekonomi sedangkan model penjelasan yang digunakan adalah kausalitas atau sebab akibat (cause and effect). Hasil penelitian ini menyimpulkan bahwa involusi pertanian di Jawa dilatarbelakangi kebijakan kolonial Hindia Belanda (1619-1942) yang membawa produk pertanian Indonesia ke pasar dunia. Namun Belanda tidak pernah berhasil mengembangkan ekonomi ekspor secara luas di pasar dunia. Untuk itu kolonial Belanda terus mendorong petani untuk berproduksi untuk memenuhi kebutuhan pasar dunia. Untuk itu Belanda menerapkan sistem tanam paksa 18301870 dan sistem liberal 1870-1900. Penerapan dua sistem ini menyebabkan banyaknya lahan pertanian yang digunakan untuk menanam tanaman ekspor dan menyerap tenaga kerja. Artinya, lahan pertanian makin sempit sedangkan jumlah penduduk makin bertambah. Hal inilah yang disebut dengan proses involusi yang kemudian akan menyebabkan petani akan berfikir keras dalam mengelola sawahnya, karena lapangan kerja di luar pertanian tidak tersedia. Kondisi ini membawa dampak bagi desa atau masyarakat Jawa: terjadinya involusi pertanian dan kemiskinan bersama; semakin kuatnya pemilikan tanah komunal, pengembangan produksi palawija, semakin sulitnya pembagian kerja serta untuk memperoleh pendapatan.
\end{abstract}

Kata kunci: Involusi, Pertanian, Jawa.

\section{PENDAHULUAN}

Sejarah pertanian di Indonesia adalah sejarah penyimpangan yang telah mewariskan pokokpokok persoalan structural di sector pertanian yang masih bertahan hingga saat ini. Ketika Negara-negara Barat, pertanian dimulai dengan membagi-bagikan lahan pertanian kepada rakyat (land reform), di Indonesia terjadi sebaliknya, tanah rakyat "dirampas" untuk dibagi-bagikan kepada pengusaha swasta. Pembangunan di sektor pertanian yang dilakukan oleh kaum penjajah seperti Belanda, Inggris, Spanyol, dan Portugis di negera-negara Asia Tenggara adalah upaya ekploitasi guna mendukung pertumbuhan ekonomi di negara masing-masing. Menurut Koentjaraningrat (1979:343), kolonialisasi pada suatu bangsa pada hakekatnya ialah suatu usaha eksploitasi kekayaan dan penindasan terhadap bangsa lain. Tidak terkecuali praktek kolonialisasi yang dilakukan oleh Belanda yang dilakukan terhadap penduduk Hindia Belanda dengan berbagai cara dan sistem yang diterapkan.

Pada awalnya istilah involusi dipakai oleh para antropolog dalam meneliti suatu bentuk kesenian. Konsep involusi ini diperoleh dari Alexander Goldenweiser, seorang ahli antropologi dari Maerika Serikat, yang telah menciptakannya untuk melukiskan pola-pola kebudayaan yang sudah mencapai bentuk yang nampaknya telah pasti tidak berhasil menstabilisasinya atau mengubahnya menjadi suatu pola baru, tetapi terus berkembang ke dalam sehingga menjadi semakin rumit (Geertz, 1976:88). Istilah involusi kemudian dipakai oleh Geertz dalam masalah pertanian. Menurut Geertz (1976:xxiii) involusi pertanian adalah kemandekan atau kemacetan pola pertanian yang ditunjukan oleh tidak adanya kemajuan yang hakiki. Jika pun ada gerak misalnya orang berjalan, berlari atau menunjukan gerakan yang lain di dalam lingkungan air, tak ada gerakan 
yang menimbulkan kemajuan. Sedangkan dalam pertanian, involusi digambarkan oleh taraf produktivitas yang tak naik, dimana produktivitas perorangan (tenaga kerja) yang dipakai sebagai ukuran. Kenaikan hasil perhektar memang dicapai tapi hasil yang lebih tinggi itu hanya cukup untuk mempertahankan penyediaan pangan perorang, pemakan nasi.

Menurut Geertz involusi ialah perubahan yang hampir tidak terjadi perkembangan karena terbagi, maksudnya kenaikan jumlah produksi bersamaan dengan melonjaknya jumlah penduduk (produksi mengikuti deret ukur, jumlah penduduk mengikuti deret hitung). Pengertian dari Involusi yang lain ialah meningkatnya jumlah penduduk tanpa dibarengi penambahan lahan garapan sehingga mereka kemudian terpaksa membagi lahan pertanian sama-rata, sama-rasa. Arti involusi oleh Geertz disebabkan juga pada satuan usaha lain bukan hanya pertanian bahkan juga pada satuan-satuan sektor, misalnya perdagangan dan industri rumah tangga; karena amat banyaknya orang melakukan fungsi itu, keuntungan masingmasing hanya tipis (Geertz, 1976:xxvii). Menurut pengamatannya, Geertz tidak lepas dari periodisasinya terhadap penjajahan di Jawa yakni periode masa VOC, masa tanam paksa, dan masa sistem perkebunan swasta. Geertz menyipulkan periode kedua-lah yang berperan penting dalam dalam timbulnya involusi.Involusi ini ditandai dengan terjadinya dualisme ekonomi: (a) Kehidupan ekonomi kolonial yang bersifat kapitalis bejalan diatas sistem atau lembaga tradisional. Karena sistem ekonomi kolonial berjalan sendiri. Tidak akan mungkin akan bisa hidup; (b) Adanya hubungan sekaligus pertarungan antara sistem kapitalis dengan tradisional. Ekonomi barat yang bersifat kapilastik menjalankan kegiatanya dengan menggunakan alat dalam bentuk kontrak, uang, jual beli dan lain-lain. (http://historycomunity. blogspot.com/favicon.ico, di akses, 10 Juni 2018). Geertz menggambarkan ciri involusi adalah "tumbuh ke dalam", bukan mekar atau merubah diri. Dalam hal ini, penduduk yang luar biasa besarnya diserap oleh sawah yang terlampau sempit terutama di daerah dimana penanaman tebu. Berdasarkan uraian di atas, permasalahan dalam penelitian ini adalah faktor apakah yang melatarbelakangi terjadinya involusi pertanaian di Jawa, bagaimakah proses terjadinya involusi pertanian dan terhadap desa di Jawa.

\section{METODE PENELITIAN}

Helius Sjamsuddin menjelaskan bahwa metode berarti cara, jalan, petunjuk pelaksana atau petunjuk teknis yang sistematis dalam suatu pendidikan ilmu tertentu untuk mendapatkan obyek (Sjamsuddin, 2007:24). Sedangkan J. Garragham menjelaskan metode penelitian sejarah adalah seperangkat aturan atau prisip sistematis untuk mengumpulkan sumber-sumber sejarah secara efektif, menilainya secara kristis, dan mengajukan sintesis dari hasil-hasil yang dicapai dalam bentuk tertulis (Abdurrahman, 2007:53).

Berdasarkan pengertian di atas para ahli ilmu sejarah sepakat untuk menetapkan empat kegiatan pokok di dalam cara meneliti sejarah. Gottschalk (1983) mensistematisasikan langkahlangkah dalam metodologi sejarah itu sebagai berikut; (a) mengumpulkan obyek yan berasal dari suatu zaman dan mengumpulkan bahanbahan tertulis dan lisan yang relevan; (b) menyingkirkan bahan-bahan yang tidak autentik; (c). menyimpulkan kesaksian yang dapat dipercaya berdasarkan bahan-bahan yang autentik; (4) menyusun kesaksian yang dapat dipercaya itu menjadi kisah atau penyajian yang berarti (Abdurrahman (2007:54)

Langkah pertama adalah Heuristik, GJ. Renier menjalaskan teknik mengumpulkan sumber disebut heuristik yang berarti memperoleh (Abdurrahman, 2008:64). Selanjutnya dijelaskan bahwa heuristik adalah suatu teknik, suatu seni bukan suatu ilmu oleh karena itu heuristik tidak mempunyai peraturanperaturan umum. Dalam mengumpulkan sumber peneliti melakukan studi pustaka. Menurut Koentjaraningrat teknik kepustakaan merupakan cara pengumpulan data bermacammacam material yang terdapat di ruang kepustakaan, seperti koran, buku-buku, majalah, naskah, dokumen dan sebagainya yang relevan dengan penelitian (Koentjaraningrat, 1983:420). 
Setelah peneliti mengumpulkan sumber-sumber sejarah tahap berikutnya adalah kritik sumber (verifikasi) untuk memperoleh keabsahan (Abdurahman, 2008:68). Tahap ini dapat dilakukan baik kritik eksternal maupun kritik internal.

Setelah sumber tersebut terkumpul maka langkah selanjutnya adalah melakukan kritik terhadap sumber, baik itu kritik intern maupun ekstern. Kritik ekstern berupa menguji keaslian dari sumber berupa segi-segi luarnya misalnya mengujian dengan pertanyaan berupa kapan sumber itu dibuat, siapa pembuat sumber sejarah tersebut, dari bahan apa sumber itu dibuat, apakah sumber itu masih dalam bentuk asli? Setelah itu kita melakukan kritik intern yang menguji isi kandungan sumber tersebut dengan pertanyaan apa dan bagaimana isi kandungan sumber tersebut. Hal ini dapat dilakukan dengan kritik internal negatif dan kritik internl positif. Tahap selanjutnya adalah interpretasi atau analisis. Interpretasi berarti menafsirkan atau memberi makna kepada faktafakta adau bukti-bukti sejarah (Daliman, 2012:81). Tugas peneliti memberikan penafsiran dalam kerangka memugar suatu rekonstruksi masa lampau. Analisis sendiri bertujuan melakukan sintesis (menggabungkan) atas sejumlah fakta yang diperoleh dari sumbersumber sejarah dan bersama teori disusunlah fakta itu dalam suatu interprestasi yang menyeluruh (Abdurrahman, 2007:73). Tahap terakhir adalah histiriografi yaitu proses penyusunan fakta sejarah dan berbagai sumber yang telah diseleksi dalam bentuk tulisan sejarah (Sulasman, 2014:147). Model penjelasan yang digunakan adalah kausalitas untuk meneropong faktor-faktor penyebab sebuah peristiwa terjadi. Menurut Carr (1971), Dalam sejarah dapat dibedakan sebab umum (general cause, findamental sause), dan sebab khusus (direct cause, immadiate cause) atau yang menjadi pemicu (trigger). Kausalitas merupakan model penjelasan sejarah dengan merangkai fakta dalam hubungan sebab akibat (cause and effect). Hukum sebab akibat mengingatkan bahwa setiap fenomena merupakan akibat dari sebab sebelumnya (Pranoto, 2010:45).

\section{HASIL DAN PEMBAHASAN}

\section{Sebab-sebab terjadinya Involusi Pertanian di Jawa}

Memahami bagaimana latarbelakang terjadi involusi pertanian di Jawa Wasino (2008:11) menjelaskan; Involusi ini sesungguhnya telah memiliki akar jauh sebelum kolonialisme, tetapi dipercepat dengan hadirnya perkebunan tebu pada masa tanam paksa dan semakin dipercepat lagi pada masa kolonial liberal”. Hal ini bisa kita lihat, pertama, kebijakan kolonial Hindia Belanda (1619-1942) adalah membawa produk pertanian Indonesia yang subur ke pasar dunia, dimana pada saat itu produk dari Indonesia ini sangat dibutuhkan dan laku keras dalam pasaran, tanpa mengubah struktur ekonomi masyrakat. Hal ini dimungkinkan karena pada Maret 1602, perseroan-perseroan yang saling bersaing bergabung membentuk Perserikatan Maskapai Hindia Timur, VOC (Vereenigde Oost Compagnie) yang bertujuan meningkatkan daya saing dengan pedangan-pedagang erapa lainnya seperti Inggris, Spanyol dan Portugis. Tahun 1619 setelah Inggris dihalau oleh tentara Banten, pasukan VOC di bawah Piter Coen merebut Jayakarta dan membangun markas VOC dan mengganti namanya menjadi Batavia. Menurut Wasiono (2008:23) "sejak tahun 1680, VOC berhasil menguasai semua jalur perniagaan rempah-rempah di Nusantara. Para pedagang sing di luar Belanda yang semula berdagang dengan penduduk Indonesia dihalau melalui "administrative trade". VOC menjadi pemain utama (monopoli) perdagangan rempah-rempah di Indonesia.

Namun, pemerintah kolonial tidak pernah berhasil mengembangkan ekonomi ekspor secara luas di pasar dunia, seperti halnya Inggris pada masa yang sama, sehingga kepentingan utama Pemerintah Belanda tetaplah bertumpu pada koloninya, Hindia Belanda. Kedua, upaya pemerintah kolonial untuk meraih pasar internasional adalah mempertahankan pribumi tetap pribumi, dan terus mendorong mereka untuk berproduksi bagi memenuhi kebutuhan pasar dunia. Pada tahun 1830-1870 pemerintah kolonial Belanda menjalankan Cultuurstelsel di 
Indonesia, khususnya di Jawa. Cultuurstelsel adalah istilah resmi pengganti cara produksi yang tradisional dengan cara produksi yang rasional, disebut juga dengan istilah "tanam paksa" oleh kaum liberal yang anti cara itu karena dianggap sebagai usaha pemerintah yang dalam pelaksanaannya menggunakan cara-cara paksaan (Mudjanto,1987:17).

Pemerintah kolonial Belanda menjalankan tanam paksa tersebut karena kas negara kosong, akibat terjadinya revolusi Belgia tahun 1830 dan beberapa peperangan di Hindia Belanda. Sehingga timbullah gagasan untuk memeras tanah jajahan yang mempunyai latar belakang pertanian untuk mengisi kekosongan kas negara tersebut. Pencetus gagasan tanam paksa adalah Johannes van den Bosch, seorang penasehat raja Willem I yang kemudian diangkat menjadi Gubernur Jendral di Indonesia. Dia sangat yakin akan keberhasilan gagasannya melihat keadaan tanah di Jawa yang subur dan banyak tenaga kerja yang diambil dari masyarakat desa yang cukup padat. Pada dasarnya tanam paksa itu berarti pemulihan sistem eksploitasi berupa penyerahan wajib yang pernah dipraktekkan VOC sewaktu berkuasa dahulu.

Jenis tanaman yang terkena sistem tanam paksa terutama adalah kopi, tebu, dan nila (indigo). Sedangkan tanaman lain yaitu tembakau, lada, teh, dan kayu manis ditanam dalam skala kecil. Komoditi tersebut ditanam pada $1 / 5$ bagian tanah penduduk, kecuali kopi yang ditanam di tanah-tanah yang belum digarap. Wilayah tanam paksa terutama di Jawa, khususnya di daerah gubernemen, dengan pengecualian daerah Batavia, Bogor, daerah tanah partikelir dan daerah Vorstenlanden. Di daerah Vorstenlanden ada aturan khusus yaitu dengan sistem sewa (Kartodirdjo, dkk., 1991:57). Kalau kita cermati, antara sistem eksploitasi VOC dengan pemerintah kolonial terdapat persamaan yaitu dalam hal penyerahan wajib hasil-hasil pertanian penduduk desa, meskipun cara pelaksanaannya agak berbeda, pemerintah kolonial Belanda secara langsung mengadakan hubungan dengan para petani yang secara efektif menjamin arus tanaman eksport dalam jumlah yang dikehendaki tanpa harus menghubungi terlebih dahulu para bupati dan kepala desa (Sartono, 1976:75).

Tanam paksa lebih mengutamakan peningkatan hasil produksi tanaman eksport yang sangat laku di pasaran Eropa. Untuk itu pemerintah kolonial memperkenalkan tanaman eksport kepada petani di Jawa. Maka dalam pelaksanaan tanam paksa itu dipergunakan desa sebagai organisme: yaitu tanah, pekerja dan pimpinan, yang merupakan satu kesatuan yang tidak dapat dipisahkan. Ke tiga faktor itu apabila di organisasi dengan baik dapat memberikan hasil produksi eksport yang tinggi. Menurut ketentuan Lembaran Negara (Staatsblad) tahun 1834 No. 22 ketentuan pelaksanaan sistem tanam paksa adalah sebagai berikut: 1) Persetujuan akan diadakan dengan penduduk di mana penduduk akan menyediakan sebagian dari tanahnya untuk penanaman tanaman perdagangan yang dapat dijual di pasaran Eropa; 2) Bagian dari tanah pertanian yang disediakan penduduk untuk tujuan ini tidak diperbolehkan melebihi seperlima dari tanah pertanian yang dimiliki oleh penduduk desa; 3) Pekerjaan yang diperlukan untuk menanam tanaman perdagangan tidak boleh melebihi pekerjaan yang diperlukan untuk menanam padi; 4) Bagian tanah yang disediakan untuk menanam tanaman perdagangan dibebaskan dari pembayaran pajak tanah; 5) Tanaman perdagangan yang dihasilkan di tanah yang disediakan wajib diserahkan kepada pemerintah Hindia Belanda; jika nilai hasil tanaman perdagangan yang ditaksir itu melebihi pajak tanah yang harus dibayar rakyat, maka selisih positifnya harus diserahkan kepada rakyat; 6) Panen tanaman perdagangan yang gagal harus dibebankan kepada pemerintah, sedikitnya jika kegagalan itu tidak disebabkan oleh kelalaian rakyat; 7) Penduduk desa akan mengerjakan tanah di bawah pengwasan kepalakepala, sedangkan pegawai-pegawai Eropa hanya akan membatasi diri pada pengawasan pembajakan tanah, panen, dan pengangkutan tanaman agar bisa berjalan dengan baik dan tepat pada waktunya (Fauzi, 1999:320).

Pelaksanaan tanam paksa dalam kenyataannya tidak sesuai dengan peraturan yang berlaku pada masa itu. Menurut ketentuan, 
pemerintah kolonial seharusnya mengadakan perjanjian dengan rakyat terlebih dahulu, tetapi dalam prakteknya, dilakukan tanpa perjanjian dengan penduduk desa sebelumnya dan dengan cara paksaan. Sehingga, banyak terjadi penyelewengan dan penyalahgunaan kekuasaan yang dilakukan oleh pegawai kolonial, bupati dan kepala desa itu sendiri mengakibatkan timbul penderitaan pada penduduk desa yang bersangkutan. Bupati dan kepala desa bekerja bukannya mengabdi kepada kepentingan rakyat desa melainkan kepada pemerintah kolonial atau demi kepentingan pribadi, membuat merosotnya martabat dan kewibawaan pejabat-pejabat yang bersangkutan dan juga dianggap sebagai kaki tangan pemerintah kolonial (Elisabet,1988:4).

Pada tahun 1840, Cultuur Stelsel sudah menghadapi berbagai masalah (Ricklefs, 2008:268). Tanda-tanda tentang penderitaan di kalangan orang Jawa dan Sunda mulai nampak, khususnya di daerah pertanian tebu. Pada tahun 1848, untuk pertama kali sebuah undangundang yang liberal memberikan kepada parlemen Belanda peranan yang berpengaruh kepada daerah jajahan dan hasil perdebatan politik di Belanda adalah dihapuskannya tanam paksa. Oleh karena itu sejak tahun 1870 tanam paksa dihentingakan, sebagai gantinya antara tahun 1970-1900 pemerintah kolonial Belanda menerapkan system liberalisme sebagai sistem ekonominya di Hindia Belanda (Kartodirdjo, dkk., 1977:97).

Pada tahun 1870 keluarlah Undang-undang Agraria (Agrarische Wet) yang disusun oleh menteri de Waal. Undang-undang ini menerangkan bahwa: 1) Pemerintah berhak menyewakan tanah yang tidak dipergunakan penduduk asli selama 75 tahun, kepada bangsa asing. Peraturan ini disebut erfpacht artinya tanah yang dapat diwariskan; 2) Penduduk asli tidak boleh menjual tanahnya kepada orang asing, tetapi boleh menyewakannya (misalnya untuk tanaman tebu); 3) Tanah-tanah yang tidak dimiliki oleh siapapun juga, menjadi hak milik pemerintah.

Ada dua macam tanah, yaitu: 1) Tanah bebas: (egendom/milik sendiri), recht van opstal (untuk mendirikan bangunan, erfpacht (tanah sewa selama 75 tahun), dan lain-lain; 2) Tanah tidak bebas: milik anak negeri, tanah swasta, yaitu tanah yang dijual kepada bangsa asing oleh pemerintah. Tanah tidak bebas tidak boleh pindah dari tangan anak negeri.

Dengan diterpakannya sistem ekonomi liberal ini, berarti tercipta kesempatan bagi kaum liberal Belanda untuk menginvertasikan modalnya di perkebunan-perkebunan besar di Hindi Belanda secara bebabas. Produktivitas perkebunan dan volume perdagangan kemudian berkembang secara pesat, sehingga terjadi, penanaman modal secara besar-besaran (Kartodirdjo, 1972:15). Beberapa jenis tanaman perkebunan yang dibuka seperti tebu, kopi, tembakau, teh, kina dan lain-lain. Ada tiga faktor yang menyebabkan perkembangan swasta Barat dalam perkebunan di Jawa; tersedianya tanah dan tenaga kerja, investasi modal dan jaringan pemasaran hasil produksi (Wasino, 2008:31).

Tujuan awal dikeluarkannya UU Agraria ini untuk melindungi tanah-tanah pribumi dari perkebunan besar milik swasta Barat, namun pada kenyataannya hanya melindungi para pemilik modal eropa yang menanmkan modalnya di perkebunan dan tetap membuka kondisi-kondisi yang menguntungkan mereka, misalnya tenaga kerja yang sangat murah (Kartodirdjo, 1972:28-29). Oleh sebab itu kondisi Hindia Belanda mendapat kritikan dari kaum liberal, agar pemerintah Belanda tidak semata-mata memikirkan ekonomi saja tetapi juga memperhatikan nasib penduduk pribumi. Pada tahun 1899, muncul ide mengenai politik etis yang diprakarsai Conrad Theodore van Deventer seorang ahli hukum. Ia menulis dalam majalah Belanda De Gids, dengan judul "Een Ereschuld" yang artinya utang budi. Di dalam majalah itu mengkritik pemerintah belanda yang telah mendapat berjuta-juta gulden dari hasil penjajahan di Hindia Belanda. Kritikan juga datang dari partai Protestan yang memperoleh kemenangan dalam pemilihan umum di Belanda, pada tahun 1891 mengkritik kebijakan kolonial yang mengakibatkan penderitaan penduduk Hindia Belanda (Wasino, 2008:33).

Pelaksanaan politik liberal membawa dampak sebagaimana hasil penelitian komisi Mindere 
Welvaart Commisie yang dilakukan pada tahun 1900. Hasilnya; kondisi perekonomian daerah jajahan khususnya daerah pedesaan Jawa pada penghujung abad 19 menunjukan ketimpangan. Salah satu indokator yang jelas adalah menurunnya konsumsi beras dari 120 $\mathrm{kg} /$ pertahun perkapita pada tahun 1800, menurun menjadi $1033 \mathrm{~kg} /$ tahun pada tahun 1900. Hasil penyelidikan diumumkan oleh ratu Wilhelmina pada tahun 1901, sehingga sejak saat itu secara resmi politik Etis mulai dilaksanakan (Wasino, 2008:35).

\section{Proses Terjadinya Involusi Pertanian di Jawa}

Pemerintah kolonial dalam usaha meningkatkan produksi eksportnya menentukan tanaman yang memberikan keuntungan besar seperti tebu dan kopi. Tanaman tebu merupakan tanaman tahunan yang membutuhkan irigasi, dan dapat ditanam di sawah, sehingga memungkinkan dapat menanam tebu dan padi bergantian. Tanaman tebu juga tidak cukup kalau hanya mengandalkan pada tanah yang luas, tanpa diimbangi oleh irigasi jalan raya dan sebagainya. Penduduk desa pada dasarnya mempunyai jiwa sosial yang tinggi, sehingga mereka melakukan pekerjaan-pekerjaan itu dengan semangat gotong royong dan kekeluargaan, hal inilah yang disalahgunakan oleh penguasa dan pemerintah kolonial untuk mempekerjakan mereka dan memberi upah yang minim (Boeke, 1983:25). Pendirian pabrikpabrik gula berarti banyak tanah desa yang dipergunakan untuk menanam tebu. Hasil produksi tebu yang meningkat mengakibatkan harus memerlukan banyak tenaga penduduk desa.

Berdasarkan pengalaman dalam kerja paksa ini membuat para penguasa swasta mendapat keuntungan besar dari hasil kontrak gula dengan pemerintah kolonial. Para penguasa swasta mulai berani menggunakan "kerja bebas" yaitu upah yang tidak berdasarkan paksaan melainkan berdasarkan persetujuan sukarela. Jalan-jalan dan alat-alat pengangkutan diperbanyak karena itu penguasa Eropa di Jawa berusaha untuk mengadakan ekspansi (Burger, 1977:204).

Sistem tanam paksa sangat menentukan dalam pemusatan pertanian di Jawa. Sistem itu telah memberikan bentuk terakhir pada perbedaan yang ekstrim antara Jawa dan luar Jawa dan semenjak itu perbedaan semakin besar. Sistem Tanam Paksa telah memantapkan pola ekonomi rangkap dengan sektor barat yang padat modal dan sektor timur yang padat karya. Sistem Tanam Paksa telah menyebabkan makin pesatnya perkembangan sektor barat dan membekukan sektor timur. Selain itu sistem ini telah mencegah pengaruh akibat makin mendalamnya penetrasi barat ke dalam kehidupan petani dan priyayi Jawa, sehingga modernisasi pertanian di kalangan pribumi pada saat yang sangat menguntungkan.

Pada masa tanam paksa itu, jenis tanaman dipisahkan dalam dua kategori yaitu: tanaman tahunan: tebu, nila, tembakau dan tanaman keras: kopi, teh, lada, kina, kayu manis (Greerts; 1983:56). Dua kategori tanaman ini menimbulkan berkembangnya dua gaya saling mempengaruhi: tanaman tahunan cenderung untuk membentuk hubungan mutualis (timbal balik) dengan komunitas, bersama-sama mempergunakan habitat tanpa menimbulkan ketegangan. Tanaman keras cenderung kearah hubungan insuler, menempati habitat yang belum dipergunakan dan menutup diri dari sistem-sistem pribumi sebagai kantong-kantong yang memang wajar.

Tanaman yang dapat mewakili dua jenis tanaman dari sistem tanam paksa adalah; tanaman tebu (termasuk tanaman tahunan) dan tanaman kopi (termasuk tanaman keras) keduanya adalah tanaman yang mempergunakan lahan yang luas, menyerap tenaga keraja yang cukup besar, menghasilkan keuntungan yang tinggi atau mempunyai pengaruh yang relatif lama terhadap struktur umum ekonomi rakyat petani.

Tebu merupakan tanaman yang butuh irigasi sehingga harus ditanam di sawah. Tebu memakai pajak berdasarkan 1/5 tanah petani. Sedangkan kopi merupakan tanaman yang cocok ditanam di daerah pegunungan dan tidak membutuhkan irigasi sehingga ditanam di daerah selain daerah tanaman padi. Pajak dari kopi berdasarkan padat karya, taksiran diambil dari segi jumlah pohon kopi yang harus dipelihara oleh orang yang 
ditunjuk untuk menanamnya. Ironisnya yang terjadi ialah sebaliknya. Dalam 3 dasawarsa terakhir dari zaman penjajahan, kurang lebih hanya $6 \%$ produksi kopi Indonesia berasal dari pemilik lahan kecil, sedangkan lebih dari 95\% produksi gula berasal dari perkebunanperkebunan milik Belanda yang ada di Jawa.

Produksi kopi dengan cepat meningkat dalam waktu 10 tahun. Pada tahun 1813 di Jawa, terdapat lebih dari 100.000 batang pohon kopi, dua tahun kemudian 1835 berlipat menjadi 2 kali lipat, dan pada tahun 1840-1850 lebih dari 3 kali lipat jumlah tersebut. Selama periode sistem tanam paksa, kopi untuk Jawa sama dengan tekstil untuk Inggris. Berbeda dengan kopi, gula tidak meningkat dengan pesat saat pertama kali diadakan sistem tanam paksa. Justru ketika kopi mengalami stagnanisasi produksi dari gula semakin meningkat.

Peningkatan produksi ini ternyata hanya menguntungkan pihak Belanda. Sedangkan bagi pihak pribumi kurang diuntungkan karena pihak Belanda tidak melibatkannya dalam keuntungan yang diperoleh dari kedua tanaman ekspor tersebut. Hal ini kemudian diperparah dengan lahan yang dipakai sebagai lahan tanaman pangan tidak mengalami peningkatan sehingga produsipun tidak mengalami peningkatan yang berarti bila dibandingkan dengan pertumbuhan jumlah penduduk. Reinsma menjelaskan, pada tahun 1830 terdapat 7.000.000 jiwa penduduk di Jawa, tahun 1840 kemudian bertambah menjadi 8.700 .000 jiwa, tahun 1850 menjadi 9.600 .000 jiwa, 1860 menjadi kurang lebih 12.700 .000 jiwa, 1870 menjadi 16.200.000 jiwa, 1880 berubah menjadi 19.500.000 jiwa, pada tahun 1890 mengalami penurunan akibat banyaknya wabah menjadi 13.600.000 jiwa, akan tetapi pada tahun 1900 jumlah ini telah menjadi 28.400 .000 jiwa. Kenaikan jumlah penduduk jawa saat itu kurang lebih 2\% selama 10 tahun (Geertz, 1976:76). Ketika peningkatan ini terjadi orang-orang Jawa khususnya petani memiliki dua posisi keadaan yang paling jelek yaitu ekonomi yang mandek atau stagnan dan jumlah penduduk yang terus meningkat. Keadaan inilah yang kemudian sering disebut dengan involusi pertanian.
Memasuki tahun 1870 terjadi perubahan iklim politik di Belanda yang sekaligus mempengaruhi kebijakan di Hindia Belanda. Pada tahun 1870 Belanda mengeluarkan Undang-Undang Agriria. Ditambah dengan berbagai peraturan tambahan undang-undang itu memungkinkan pemindahan tanggungjawab secara langsung agar pulau Jawa tetap menguntungkan bagi usaha-usaha swasta serta untuk mencegah agar usaha-usaha serupa tidak menghancurkan ekonomi desa yang menjadi landasan tempat mendapatkan keuntungan (Geertz, 1976:91).

Beberapa perusahaan perkebunan didirikan seperti Nederlanshe Handel Maatschappij (NHM) yang didirikan pada tahun 1824 yang kemudian menjadi firma penanaman modal swasta yang setengah bank dan setengah perkebunan. Pada tahun 1915 Maskapai ini telah memiliki enam belas buah pabrik gula dan secara efektif mengontrol dua puluh buah lainnya, empat buah perkebunan tembakau, dua belas perkebunan teh dan empat belas buah perkebunan karet. Pada tahun 1878 didirikan Handels Veerenaingen Amsterdam (HVA). Perusahaan ini telah mengontrol empat belas pabrik gula dan mengelola satu pabrik tapioka, satu gabungan perkebunan kopi-karet dan dua puluh perusahaan perkebunan yang sudah berdiri sejak zaman tanam paksa. Sedangkan pabrik gula didirikan pada tahun 1913 yang bernama Cultuur Maatschappij der Vorstenlanden. Perusahaan ini telah memiliki dua puluh pabrik gula, tiga perkebunan kopi, satu tembakau dan satu teh (Geertz, 1976:93).

Perusahaan-perusahaan perkebunan ini secara financial didukung oleh bank-bank seperti Handelsbank, Charteredbank yang telah mendisferifikasi produksi perkebunan jauh dari produk utama dari abad sembilan belas, gula dan kopi serta meluaskannya ke bagian-bagian tertentu ke Indonesia luar dan luar Jawa. Perusahaan-perusahaan besar ini juga membangun jalan raya, irigasi modern, balai percobaan pertanian atau secara umum menciptakan sebuah argoindustri yang menyeluruh, yang dalam hal kerumitam, 
efisiensi dan besarnya tiada bandingnya di seluruh dunia.

Pada masa perkebunan besar ini, gula tetap merupakan hasil bumi ekspor Indonesia yang paling penting sampai tahun tigapuluhan, terus menjalin hubungan yang timbal balik dengan padi, dengan samaran yang berbeda sedikit saja. Karena Jawa sudah sangat padat penduduknya maka dikembangkanlah suatu kompleks sewa menyewa tanah untuk memperoleh hak menggunakan tanah. Suatu onderneming mengadakan perjanjian penyewa tanah untuk jangka waktu 21,5 tahun yang kadang-kadang dilakukan dengan senang hati dan kadangkadang dipaksa oleh orang terkemuka dan pejabat pamong praja setempat (Geertz, 1976:95).

Penanaman tebu di Jawa, distribusi sawah dan penduduknya yang tidak merata menyebabkan petani tidak memiliki pilihan lain untuk menanggulangi kenaikan jumlah petani kecuali dengan mengusahakan sawah mereka dengan lebih giat dan bahkan seluruh sumber daya pertanian mereka dengan cara yang seksama, karena tidak akan ada industri yang menampung mereka sedang lahan pertanian kosong sudah penuh oleh tanaman tebu.

Demikianlah secara lambat laun, petani terpaksa memasuki pula sawah yang makin lama makin sesak dengan pegawai, seperti yang terlihat dari tahun 1920. Penduduk luar biasa besarnya diserap ke sawah yang terlalu sempit, terutama di daerah tebu yang telah mempertinggi mutu irigasi. Kenaikan produktivitas perhektar sebagi akibat perbaikan irigasi tersebut dan dengan bantuan palawija merupakan standar hidup yang stabil atau stagnan. Mekanisme adaptasi petani Jawa yang digambarkan oleh Geertz adalah dengan melakukan intensifikasi dengan melibatkan sebanyak mungkin tenaga dalam setiap kegiatan produksi tanaman dalam kerangka membagibagikan rejeki yang ada hingga makin lama makin sedikit yang diterima. Namun bagaimanapun, akhirnya akan menimbulkan suatu kemerosotan (proses involusi pertanian).

\section{Dampak Involusi Pertanian bagi desa di Jawa}

Clifford Geertz, terjadinya involusi pertanian dan kemiskinan bersama yang telah melahirnkan gejala tersendiri dalam masyarakat Jawa; sifat pasca tradisional dari struktur masyarakat pedesaan, semakin kuatnya pemilikan tanah komunal, pengembangan produksi palawija, semakin parahnya kemiskinan bersama dalam pembagian kesempatan kerja serta untuk memperoleh pendapatan (Wasino, 2008:11). 1) Sifat Post-Tradisional dari struktur masyarakat pedesaan. Pola dasar kehidupan desa dipertahankan dalam beberapa hal bahkan diperkuat dan penyesuaian pada kapitalisme dilakukan dengan cara lebih merumitkan berbagai pranata dan praktek yang sudah mapan. Dalam menghadapi persoalan-persoalan; meningkatnya jumlah penduduk meluasnya penggunaan uang, makin tergantungnya pada pasaran dan lain-lain, petani Jawa bukan melebur pola tradisional ke dalam anarki "proletar pedesaan" yang individualistis dan bukan pula dengan cara merubah bentuk pola itu menjadi komunitas pertanian-perdagangan yang modern (Geertz, 1976:99). Desa yang terkepung dari berbagai penjuru mempergunakan cara-cara sejenis keterampilan khusus dengan demikian dapat mempertahankan pola itu secara keseluruhan sambil mendorong unsur-unsurnya mencapai tingkat tertinggi; 2) Semakin kuatnya pemilikan tanah komunal. Dimana desa sebagai suatu badan hukum masih memiliki sisa-sisa hak kekuasan atas sawah, nampaknya malahan diperkuat, sekurang-kurangnya secara relatif di desa-desa di daerah gula; 3) Pengembangan produksi Palawija. Krisis perdagangan tahun 1885 mengakibatkan terjadinya reorganisasi dalam kehidupan ekonomi Hindia-belanda. Perkebunan-perkebunan besar tidak lagi milik perseorangan tetapi direorganisasi sebagai perseroan terbatas. Pejabat kolonial Belanda dengan giat menganjurkan pemanfaatan ubi kayu yang diimpor dari Suriname tahun 1852 . Kondisi ini diperburuk dengan makin meningkatnya penduduk Jawa setelah tahun 1900 dimana produksi beras tidak dapat mengimbanginya oleh karena itu petani mulai 
menanam apa yang secara kolektif di sebut Palawija; 4) Semakin parahnya kemiskinan bersama dalam pembagian kesempatan kerja serta untuk memperoleh pendapatan, beberapa faktor yang menyebabkan kemiskinan rakyat Indonesia khususnya Jawa yaitu: (a) Kemakmuran rakyat ditentukan oleh perbandingan antara jumlah penduduk dan faktor-faktor produksi lainnya seperti tanah dan modal. Rakyat Jawa bermodal sangat sedikit sedangkan jumlah penduduk sangat besar; (b) Tingkat kemajuan rakyat belum begitu tinggi, sehingga hanya dijadikan umpan bagi kaum kapitalis; (c) Penghasilan rakyat yang diperkecil dengan sistem verscoot (uang muka); (d) Sistem tanam paksa dihapus, namun diberlakukan sistem batiq saldo; (e) Krisis tahun 1885 mengakibatkan terjadinya penciutan dalam kegiatan pengusaha-pengusaha perkebunan gula yang berarti menurunnya upah kerja dan sewa tanah bagi penduduk.

\section{KESIMPULAN}

Involusi pertanian di Jawa dilatarbelakangi kebijakan kolonial Hindia Belanda (1619-1942) yang membawa produk pertanian Indonesia ke pasar dunia, dimana pada saat itu produk dari Indonesia ini sangat dibutuhkan dan laku keras dalam pasar dunia. Namun Belanda tidak pernah berhasil mengembangkan ekonomi ekspor secara luas di pasar dunia. Untuk itu Belanda terus mendorong petani untuk berproduksi bagi memenuhi kebutuhan pasar dunia. Untuk itu Belanda menerapkan sistem tanam paksa 1830-1870 dan sistem liberal 1870. 1900.

Penerapan tanam paksa maupun sistem setelah itu menyebabkan banyaknya lahan pertanian yang digunakan untuk menanam tanaman ekspor dan menyerap tenaga kerja, artinya lahan pertanian makin sempit. Tidak bertambahnya lahan tanam padi ini diperparah dengan laju pertumbuhan penduduk yang pesat sehingga petani harus memasukan tenaga kerja yang berlebih ke dalam sawah yang menyempit. Hal inilah yang disebut dengan proses involusi yang kemudian akan menyebabkan petani akan berfikir keras dalam mengelola sawahnya, karena lapangan kerja di luar pertanian tidak tersedia. Kondisi ini membawa dampak bagi desa atau masyarakat Jawa; sifat pasca tradisional dari struktur masyarakat pedesaan, semakin kuatnya pemilikan tanah komunal, pengembangan produksi palawija, semakin parahnya kemiskinan bersama dalam pembagian kesempatan kerja serta untuk memperoleh pendapatan.

\section{DAFTAR PUSTAKA}

Abdurrahman, Dudung, 2007, Metodologi Penelitian Sejarah, Logos Wacana Ilmu:Jakarta. Basri, MS., 2006, Metodologi Penelitian Sejarah, Restu Agung: Jakarta.

Boeke, JH., 1983, Prakapitalisme di Asia, Jakarta; Penerbit Suara Harapan.

Burger, DH., 1977, Perubahan-perubahan Struktur dalam masyarakat Jawa, Jakarta; Bhratara.

Daliman, 2012, Metode Penelitian Sejarah, Ombak: Yogyakarta.

Elisabet Endang Sri Sulastri; 1988; Pelaksanaan Cultuurstelsel di Jawa (Skripsi Sarjana pada Jurusan Pendidikan Sejarah; Fakultas Pendidikan Ilmu Pengetahuan Sosial IKIP Sanata Dharma: Yogyakarta.

Fauzi, Noer, 1999. Petani dan Penguasa. Bandung : Insist.

Gottschalk, Louis, terj. Nugroho Notosusanto, 1975, Mengerti Sejarah, Yayasan Penerbit Universitas Indonesia, Jakarta.

Greets, C, 1976, Involusi Pertanian, Bhratara: Jakarta.

Kartodidrjo, Sartono \& Djoko Suryo. 1991. Sejarah Perkebunan Di Indonesia : Kajian Sosial Ekonomi. Aditya Media: Yogyakarta.

1977, Pengantar Sejarah Indonesia Baru: 1500-1900 dari Emporium sampai Imperium; Gramedia Jakarta.

Kartodidrjo, Sartono, 1972, Kolonialisme dan Nasionalisme di Indonesia pada abad 19 dan 20, Lembaran Sejarah UGM: Yogyakarta.

Kartodirdjo, Sartono, dkk., 1976, Sejarah Nasional Indonesia IV; Debdikbud, Grafitas: Jakarta.

Koentjaraningrat, 1979, Manusia dan Kebudayaan di Indonesia, Jakarta; Djambatan. 
,1983. Metode-Metode Penelitian Masyarakat, Gramedia: Jakarta.

Moedjanto,G., 1987, Indonesia Abad ke-20, Jilid I; Kanisius; Yogyakarta

Pranoto, Suhartono. W, 2010, Teori dan Metodologi Sejarah, cet.1, Graha Ilmu: Yogyakarta.

Ricklefs, M.C., 1999, Sejarah Indonesi Modern, Yogyakarta, Gajam Mada University Press.

Sardiman, AM, 2004, Memahami Sejarah, Bilgraf Publishing: Bandung.

Sjamsuddin, Helius, 2007, Metodologi Sejarah, Ombak: Yogyakarta.

Sulasman, 2004, Metodologi Penelitian Sejarah; teori, medode, contoh aplikasi, Pustaka Setia: Bandung.

Wasino, 2008, Berjuang Menjadi Wirausahawan: Sejarah kehidupan kapitalis bumiputra Indonesia, Semarang, Universitas Negeri Semarang Press. 